\title{
Using Game Development as the Focus of Instruction
}

\author{
Frank Kurzel \\ University of South Australia, Adelaide, Australia
}

Frank.Kurzel@unisa.edu.au

\begin{abstract}
In this paper, we report on a course offering in 2009 within the media arts area where the development of a Flash game was used as a group project for a cohort that included media arts and computing students. A previous offering of this course in this longitudinal study, identified through a factor analysis of questionnaire data, a metric referred to as Difficulty with the development. A disparity in this metric between student groups became evident and efforts have been employed in subsequent iterations of the course to appease these differences.

A project based instructional methodology has been employed witin this course, and an authentic project sponsored by a credit union was used. Flash was used to develop the game and each group member was responsible the production of an equal section. Game structures like the representation of the game actions and associated scoring, were the responsibility of the whole group; students needed to be engaged with the whole process.

Peer review and assessment were embedded within the instructional methodology to ensure that students maintained their engagement. A number of assessment rubrics were used to ensure that all activities were viewed favourably. The end result was an movement on the Difficulty factor and an appeasement of the initial difference. Both cohorts agreed that the instructional methodology was satisfactory.
\end{abstract}

Keywords: games development, instructional methodologies, project based learning, peer assessment, peer review, Flash.

\section{Introduction}

A goal of current tertiary institutions is to provide authentic, student driven, collaborative, experiential learning frameworks that actively engage students in all parts of their learning. Given the ubiqiuitous nature of gaming, it is hoped that its use within the instructional process could engage the students and enhance learning. The instructional methodology known as Project Based Learn-

Material published as part of this publication, either on-line or in print, is copyrighted by the Informing Science Institute. Permission to make digital or paper copy of part or all of these works for personal or classroom use is granted without fee provided that the copies are not made or distributed for profit or commercial advantage AND that copies 1) bear this notice in full and 2) give the full citation on the first page. It is permissible to abstract these works so long as credit is given. To copy in all other cases or to republish or to post on a server or to redistribute to lists requires specific permission and payment of a fee. Contact 0HPublisher@InformingScience.org to request redistribution permission. ing (Savin-Baden, 2003), appears to be a good match for courses that employ a major interactive artifact as the main assessment piece. This methodology is based of constructivist learning theory and espouses that "knowledge can be constructed personally, through reflection and [relates ] new knowledge to prior experience, or socially, through interaction and discussion with others, 
such as teachers, other learners' (Bates, 2005, pp. 55-56).

The course Creating Interactive Multimedia, delivered in 2009, had a game as the project; it was also sponsored by an organisation that was responsible for a major Christmas Pageant and this became the theme. The Credit Union Christmas Peagant (CUCP, 2009) has a web presence that children frequent near Christmas time. The design and production of a interactive game for publishing on the website presented an authentic challenge for the student groups to work on.

This course has been used in a longitudinal study (Kurzel, 2008) where difficulties with the development environment in producing the interactive elements were identified. The skill sets required in these courses are diverse and call upon design skills, media specialist work, and programming, all within a collaborative framework. Students come from both the media arts area and a range of computing degrees, including a 4 year multimedia/computing degree. The development environment selected for the game was Flash; the results could easily be published on the organisation's website.

This paper begins with a discussion of the longitudinal study that has resulted from the identification of a disparity between the difficulty encountered in the production of a multimedia artefact by the two main student groups. An overview of the instructional methodology pursued within the course will then provide insight into instructional techniques employed to counter this difference, supported by the action research that has been conducted. An analysis of questionnaire data collected after the current offering will then be discussed in light of the use Flash as the development environment; having an authentic activity sponsored by an involved organisation will also be condisdered. In the concluding section, the author will discuss any findings and limitations of the research.

\section{Background}

I have reported on previous courses that employed major projects (Kurzel \& Rath, 2007) as part of the instructional, and also on a difficulty factor that was indentified from questionnaire data collected at the end to each offering. When an an independent variable indicating the study program of the students, for example computing, media arts, etc., was used, it was apparent that a 2 factor resolution accounting for $35 \%$ of the overall variance, was appropriate. A principal components analysis was then followed up with a factor analysis using an oblimin rotation (see Appendix A). The resulting factors were:

\section{- Instructional Methodology is OK \\ - Difficulty with the development}

From the factor where the instruction was deemed favourable, students enjoyed the authentic project that formed the basis of the instructional methodology that was pursued. Collaboration, goal setting, discussion and reflection seemed to be tasks that were favourably reported on. It also appears that even though they were initially challenged, they came to terms with the project and its solution and thought they did better than their initial impressions. The factor difficulty with the development highlighted the programming aspects required to satisfy the interactive elements of the project.

Both the InstructionOK and Difficulty factors were reduced and a $1 \mathrm{x}$ way ANOVA performed. The Arts students reported the work as relatively more difficult than the computing students with means of 2.31 and 3.04, $F(1,45)=6.17, \mathrm{p}<.001$. Given that this course is situated in the media arts stream, this was significant. Both groups agreed on the acceptability of the instructional methodology with means of 2.24 and 2.37 respectively. 
This methodology was then applied in another 3 iterations of the course in subsequent years and the instruction was varied in a number of ways to help appease this discrepancy. Subsequent means for the two groups are outlined in Table 1.

Table 1: Creating Interactive Media (INFT 2001) Factors 2006-2008

\begin{tabular}{|c|l|c|c|c|c|}
\hline \multirow{2}{*}{ Factors } & & $\begin{array}{c}\mathbf{2 0 0 6} \\
\text { S2 }\end{array}$ & $\begin{array}{c}\mathbf{2 0 0 7} \\
\text { S1 }\end{array}$ & $\begin{array}{c}\mathbf{2 0 0 8} \\
\text { S1 }\end{array}$ & $\begin{array}{c}\mathbf{2 0 0 8} \\
\text { S2 }\end{array}$ \\
\hline \multirow{2}{*}{ InstructionOK } & Media Arts & 2.24 & 2.19 & 2.29 & 2.15 \\
& Computing & 2.37 & 2.34 & 2.52 & 2.44 \\
\hline \multirow{2}{*}{ Difficulty } & Media Arts & 2.31 & 2.39 & 2.24 & 2.24 \\
& Computing & 3.04 & 2.87 & 2.77 & 2.20 \\
\hline
\end{tabular}

Note that the response options were scored from 1 to 5 corresponding to strongly agree/ agree/ neutral/ disagree/ strongly disagree; the lower the number, the greater the agreement.

Both groups over the study responded favourably to the instructional methodology with little fluctuation in their respective means. However, one might put a case for the media arts students favouring it more. The media arts group consistently found a difficult elements while the computing students increasingly agreed with this in each subsequent offering. The results in $2008(\mathrm{~N}=25)$ saw the two groups come closer together with respect to the difficulty factor.

An interpretation of this is could be that the teaching, the resources provided, and the project based instructional methodology, with the collaboration that followed, and the support that they were given, ensured that the students were on an equal footing. However, the smaller numbers in the survey may well have skewed the results; another course offering happened in S2 of 2009.

\section{Instructional Considerations}

I believe that Project Based Learning as an instructional methodology is a good match for the course Creating Interactive Media where the aim is for students to develop the knowledge, experience and skills for the creation of effective multimedia. Further, it gels well with the overall aim of university study of engagement through through experiential learning (UniSA, 2009). Gaming provides intrinsic motivation (Habgood, 2005) for students so hopefully creating games has a similar effect (Blanchfield, 2008).

In previous iterations of this course that didn't produce games, students would be provided with specifications that they would critically analyse; they would then participate in the many phases involved in the creation of the interactive artifact. Gaming however, has the benefit of being well known and practised by the students. The course does provide some scaffolding for this process with timelines clearly outlining when game proposals, designs and productions were to be completed. These assessment requirements imposed a linear structure on the project development consistent with the waterfall model; however, it was more agile in reality. Groups of 3 students were organised based on their skill set; each group needed to have a programmer and someone with graphic skills at a minimum.

When presented with the project outline, the groups created a multimedia treatment for the game (Stansbury, 1998) outlining their ideas. Each group also published a brief outline of their game ideas on a discussion forum. The 'multimedia' nature of the treatment meant that they could use a range of features to get across their ideas, including character representations, possible scenes, example animations etc. This was presented to their peers as well as to the clients, one of which 
being a member of the target audience. Both events provided a preliminary review for the groups and what they intended. Any feedback could then be used prior to the assessment submission. The resulting game scenarios were certainly all different.

Design documents including scripts were written, navigation structures were devised, and complete storyboards were constructed to specify ideas. To ensure that each student was involved in the process, each student was responsible for an equal section of the game space. The group as a whole was responsible for the game structure; for example, if the major game task was to collect items within the game, then the notion of an inventory was devised with a corresponding interface (series of commands). This was an attempt to abstract over the programming difficulties encountered by the arts students so that they could consider them in the same way as they do normal Flash commands.

Within a storyboard page, the player might have picked up an item by clicking on it. The action in response to this click would have involved adding this item to the inventory, for exmple addToInventory(item). Production shells were developed at his stage to ensure that each project provided navigation around the game space - it consisted of a number of individual Flash files with a demonstation that game related actions could be used. Each group presented their designs, and peer review was sought; this tended to indicate the standard of work that was required. As Falchikov (1996) has reported on, peer review is an appropriate way to highlight inadequacies in the work while still providing time for these suggestions to be re-incorporated into assessable artefacts.

Peer and self assessment were introduced into the course to provide a better match to the group project work that was being conducted (Wood, 2008). Hanrahan and Isaccs (2001) have argued that self and peer assessment skills help students develop life long learning skills; self assessment helps students set goals while peer assessment helps them to contribute constructively in collaborative efforts. Each assessment piece employed a rubric to drive the peer assessment. The final mark for each group assignment as decided upon by the instructor, was moderated by the peer assessment. The first assessment piece was used to familiarlise the students with the process. Both groups of students reported favourably about the structure of the assessment.

To formalise the students' understanding of gaming, a Game Object Model (Amory, 2007) was presented and discussed within coursework to indicate the possibilites. The interactive elements were accounted for in practical sessions. If groups found that they needed to, they could investigate particular development techniques on the WWW; the abundance of resources available provided a great resource. The game structure and representation once decided upon, could be embedded and progressively developed. In Flash, an interface with a class implementation provided an efficient way of handling this. Maintaining scores between plays could be handled by employing cookies, and/or by interfacing with an online database; both techniques were canvassed.

Instructional design was discussed in the course and a meaningful component needed to be embedded in the game. One group for example, focussed on being sun smart and provided the player with relevant information about the harmful affects of the sun; the game then provided information about the locations on the pageant route where sunblock and water could be obtained.

\section{Results and Discussion}

The InstructionOK and Difficulty factors were reduced from the questionnaire data and a $1 \mathrm{x}$ way ANOVA performed. In this iteration of the course and action research, the arts and computing students reported the same level of difficulty (2.68 and 2.7 respectively). When comparing this with the other offerings, we see that both cohorts found it less difficult, and significantly, to the 
same degree. It appears that the last two course offerings eliminated differences of perception between the two groups, in particular, the difficulty factor.

Both groups again responded favourably to the instructional methodology (2.27 and 1.89 respectively); the computing students on this occasion responded more favourably. Again note that a low score indicates a greater agreement with the statement. Table 2 summarizes the findings over the course offerings. Previous years have been included again for convenience.

Table 2: Creating Interactive Media (INFT 2001) Factors 2006-2009

\begin{tabular}{|c|l|c|c|c|c|c|}
\hline \multirow{2}{*}{ Factors } & & $\mathbf{2 0 0 6}$ & $\mathbf{2 0 0 7}$ & $\mathbf{2 0 0 8}$ & $\mathbf{2 0 0 8}$ & $\mathbf{2 0 0 9}$ \\
& & S2 & S1 & S1 & S2 & S2 \\
\hline \multirow{2}{*}{ InstructionOK } & Media Arts & 2.24 & 2.19 & 2.29 & 2.15 & 2.27 \\
& Computing & 2.37 & 2.34 & 2.52 & 2.44 & 1.89 \\
\hline \multirow{2}{*}{ Difficulty } & Media Arts & 2.31 & 2.39 & 2.24 & 2.24 & 2.68 \\
& Computing & 3.04 & 2.87 & 2.77 & 2.20 & 2.7 \\
\hline
\end{tabular}

On the question of assessment, there was agreement that the peer assessment of participation within the project was fair. Further, there was also agreement that the assessment structure matched the structure of the course (see Appendix B). The students responded very positively to their understanding of how to use Flash to produce a multimedia piece and they enjoyed working on an authentic project. On the review process, there was agreement that it helped the students to better reflect on their own work and in their ability to critique the work of others. There was agreement in the statement that the reviewing process enabled them to improve on the quality of their project work.

Textual responses to what the students found difficult commonly discussed problems associated with programming the game structure, and the subsequent debugging efforts involved. The use of techniques discussed previously espousing the game language, and having this defined in a class with an interface, was not taken up by all groups; two groups went their own way. Anecdotally, a number of problems associated with the scope of variables were overcome through its establishment. These responses indicated some involvement with these aspects of the project.

On the question, 'If you had another game to develop with a team of students, what would you do differently?', these responses reflect the concerns students had about the team and project management.

- 'better preproduction planning',

- 'allocate more time for group meetings so we could all work together'

- 'divide tasks more rigorously'

- 'ensure that workloads are distributed evenly'

- 'get the organising done earlier so that we could have a very strong production timeline'

- 'be more pro active and do more planning with the group'

- 'start earlier, define game language, more testing, more group meetings'

Using Flash as the development environment, enabled some software engineering principles to be embedded within the production. Modules could be established that members of the production team could take responsiblity for, the game commands and representation could be encapsulated, 
and the game language abstracted over. Within this framework, students could still experiment collaboratively and work creatively.

\section{Conclusion}

In this longitudinal study into the course called Creating Interactive Multimedia, we were able to quantify through a factor analysis of survey questions, the relative difficulty that student groups encountered with the construction of interactive multimedia projects. Appeasing this disparity has been the goal of the action research that has ensued.

This iteration of the action research supports a previous finding (Kurzel, 2008) that shielding arts students from the complexity of the development environment and allowing them to work on the graphical elements only, does not reduce the perception that the development environment is difficult to work in. It confirms that students having ownership of sections of the project, even if they can get assistance from others about certain aspects, can have a positive effect. Coupling this with an associated understanding of how each of the independent sections could be put together to form the project in total, and an appreciation of a game language that could include scoring aspects, further improves the situation.

The introduction of peer review in the assessment stages has had a positive result on the standard of work. Being able to receive comments from peers and others, and then to be able to include these suggestions in assessment pieces, seems to have had a marked effect on the overall result; peer assessment further helps in the collaborative efforts of group members. The use of rubrics outlining outcomes in the assessment process gives worth to all group member activities.

Using Flash to develop the game where each group member contributed equally and engaged in the total process, was looked upon favourably. Having an abundance of support materials on the WWW for students to research helped in the development stage because every suggested interactive element could not be handled by instruction. However, establishing a multi Flash movie structure with in-built games structure had its difficulties.

A limitation of this action research has been the small number $(\mathrm{N}=20)$ of respondents to the survey. Written responses were sought for aspects of the development but there was still a reliance on quantitative data. This did however provide the basis for a comparison with previous results. These results would have been more valid if they had been triangulated with other data from student interviews. Future research on the use of gaming within the instructional methodology will employ this.

\section{References}

Amory, A., \& Seagram, R. (2007). Game object model version II: A theoretical framework for educational game development. South African Journal of Higher Education, 17(2). 206 - 217.

Bates, A.W. (2005). Technology, e-learning, and distance education (2nd ed.). Routledge, Abingdon, Oxon.

Blanchfield, P. (2009). Using educational game design to teach software engineering. Proceedings of the 3rd European Conference on Games Based Learning, Graz Austria, 12-13 October 2009. pp. 24-29.

Boud, D., \& Falchikov, N. (2006). Learning-oriented assessment: Principles and practice. Aligning assessment with long-term learning. Assessment \& Evaluation in Higher Education, 3(4), 399-413.

CUCP. (2009). Credit Union Christmas Pageant Website. Retrieved 22nd of November, 2009 $<$ http://www.cupageant.com.au/>. 
Falchikov, N. (1996). Improving learning through critical peer feedback and reflection. Paper presented at the Different Approaches: Theory and Practice in Higher Education. Proceedings of HERDSA Conference 1996, Perth WA.

Habgood, M. P. J., Ainsworth, S. E., \& Benford, S. (2005). Endogenous fantasy and learning in digital games. Simulation \& Gaming, 36(4), 483-498.

Kurzel, F. (2008). Introducing peer review and assessment within a project based leraning framework to account for difficulty. Proceedings of Informing Science InSITE 2008, Macon, Georgia, June 12-15, 2008..

Kurzel, F., \& Rath, M. (2007). Project based learning and learning environments. Journal of Issues in Informing Science and Information Technology (IISIT), 4, 503-510. Retrieved from http://proceedings.informingscience.org/InSITE2007/IISITv4p503-510Kurz397.pdf

Hanrahan, S. J., \& Isaacs, G. (2001). Assessing self- and peer-assessment: The students' views. Higher Education Research and Development, 20(1), 53-70.

Savin-Baden, M. (2003). Facilitating problem-based learning: Illuminating perspectives. Berkshire, England: SRHE and Open University Press.

Stansbury, D. (1998). LABYRINTHS - The art of interctive writing and design. Thomson Publising.

UniSA. (2009). University of South Australia Website. Retrieved 10th of November, 2009 from http://www.unisa.edu.au/

Wood, D., \& Kurzel, F. (2008) Engaging students in reflective practice through the process of formative peer review and assessment. ATN, Adelaide. 


\section{Appendix A}

\section{Learning Environment Scale: Obimin Rotation Loadings}

\begin{tabular}{|c|c|c|}
\hline Item & Statements & Loadings \\
\hline Factor 1 & Instructional Methodology is OK (eigen 5.219 , variance 20.878 ) & \\
\hline 11 & I achieved more in this course than I thought I initially would & .791 \\
\hline 19 & $\begin{array}{l}\text { The instructional methodology provided me with enough scope to dis- } \\
\text { play my skills }\end{array}$ & .723 \\
\hline 7 & The assessment structure matched the structure of the course & .715 \\
\hline 2 & $\begin{array}{l}\text { The project based instruction in this course suited the way I like to } \\
\text { learn }\end{array}$ & .659 \\
\hline 12 & $\begin{array}{l}\text { The setting of weekly goals helped me focus on what needed to be } \\
\text { achieved. }\end{array}$ & .646 \\
\hline 23 & $\begin{array}{l}\text { I found being able to collaborate with my group in practical sessions } \\
\text { very helpful }\end{array}$ & .595 \\
\hline 8 & $\begin{array}{l}\text { The project enabled me to demonstrate the skills that I brought to the } \\
\text { group. }\end{array}$ & .582 \\
\hline 18 & $\begin{array}{l}\text { I was really satisfied with what the group ended up achieving in the } \\
\text { project work }\end{array}$ & .581 \\
\hline 13 & $\begin{array}{l}\text { I found the course initially challenging but managed to satisfy the pro- } \\
\text { ject requirements. }\end{array}$ & .546 \\
\hline 22 & I was given the opportunity to discuss and reflect on my learning & .545 \\
\hline 20 & The resources provided allowed me to satisfy the course requirements & .537 \\
\hline 24 & I enjoyed working on a project that was authentic. & .520 \\
\hline Factor 2 & Difficulty (eigen 3.476, variance 13.903) & \\
\hline 3 & I preferred working on the graphical design aspects of the course & .763 \\
\hline 4 & I preferred working on the programming in the project $(\mathrm{R})$ & .723 \\
\hline 14 & $\begin{array}{l}\text { An online helpdesk would have been helpful when I was working with } \\
\text { Director. }\end{array}$ & .687 \\
\hline 15 & $\begin{array}{l}\text { I have a good understanding of how to use Director to produce multi- } \\
\text { media pieces (R) }\end{array}$ & .621 \\
\hline 17 & $\begin{array}{l}\text { I like to be able to choose between a number of different media formats } \\
\text { representing content. }\end{array}$ & 619 \\
\hline 10 & $\begin{array}{l}\text { I would have liked to have a discussion forum with only my group } \\
\text { members }\end{array}$ & .519 \\
\hline
\end{tabular}

Notes:

(a) The response options. Scored 1 to 5, were as follows: strongly agree/ agree/ neutral/ disagree/ strongly disagree.

(b) Items score in reverse are shown by $(\mathrm{R})$.

(c) $\mathrm{n}=50$ 


\section{Appendix B \\ Review questions with means}

\begin{tabular}{|c|c|c|c|}
\hline Questionnaire Statements & Arts & Comp & Overall \\
\hline $\begin{array}{l}\text { The Project Based Instruction in this course suited the way I like } \\
\text { to learn. }\end{array}$ & 2.09 & 2.11 & 2.10 \\
\hline I preferred working on the graphical design aspects of the project & 1.82 & 1.89 & 1.85 \\
\hline I preferred working on the Flash scripting in the project & 3.0 & 2.44 & 2.75 \\
\hline $\begin{array}{l}\text { The peer assessment to measure my participation within the pro- } \\
\text { ject was fair }\end{array}$ & 2.09 & 2.11 & 2.10 \\
\hline The assessment structure matched the structure of the course & 2.36 & 1.78 & 2.10 \\
\hline $\begin{array}{l}\text { The project enabled me to demonstrate the skills that I brought to } \\
\text { the group }\end{array}$ & 1.82 & 1.67 & 1.75 \\
\hline I achieved more in this course than I thought I initially would. & 2.45 & 2.33 & 2.40 \\
\hline $\begin{array}{l}\text { I found the course initially challenging but managed to satisfy the } \\
\text { project requirements. }\end{array}$ & 2.45 & 1.78 & 2.15 \\
\hline $\begin{array}{l}\text { I have a good understanding of how to use Flash to produce a } \\
\text { multimedia piece. }\end{array}$ & 1.91 & 1.78 & 1.85 \\
\hline I found the project components difficult to come to terms with. & 2.73 & 3.44 & 3.05 \\
\hline $\begin{array}{l}\text { I was really satisfied with what the group ended up achieving in } \\
\text { the project work. }\end{array}$ & 2.27 & 1.89 & 2.10 \\
\hline $\begin{array}{l}\text { The instructional methodology provided me with enough scope to } \\
\text { demonstrate my skills }\end{array}$ & 2.55 & 1.89 & 2.25 \\
\hline $\begin{array}{l}\text { The instructional materials need to be in a range of media formats } \\
\text { to suit my learning style. }\end{array}$ & 2.36 & 2.44 & 2.40 \\
\hline $\begin{array}{l}\text { I was given the opportunity to discuss and reflect on my own } \\
\text { learning }\end{array}$ & 2.36 & 2.00 & 2.20 \\
\hline I enjoyed working on a project that was authentic. & 1.73 & 1.33 & 1.55 \\
\hline $\begin{array}{l}\text { The instructional methodology in this course suited the way I like } \\
\text { to learn? }\end{array}$ & 2.73 & 2.00 & 2.40 \\
\hline $\begin{array}{l}\text { I found the review process helped me to better reflect on my own } \\
\text { work. }\end{array}$ & 2.55 & 2.22 & 2.40 \\
\hline $\begin{array}{l}\text { I felt I developed better skill in the ability to critique the work of } \\
\text { others as a result of undertaking peer review in CIM }\end{array}$ & 2.18 & 2.56 & 2.35 \\
\hline $\begin{array}{l}\text { I was able to improve on the quality of my assignments as a result } \\
\text { of participating in the review process. }\end{array}$ & 2.09 & 1.89 & 2.00 \\
\hline
\end{tabular}

Notes:

(a)The response options. Scored 1 to 5, were as follows: strongly agree/ agree/ neutral/ disagree/ strongly disagree.

(b) $n=20$ 


\section{Biography}

Frank Kurzel is a lecturer in the School of Communication, Information and New Media of the University of South Australia. He currently a Program Director for the Bachelor of Media Arts within the University of South Australia. He has had extensive experience in Education, Computer Science and Multimedia areas. His research interests include web-based instructional systems to support his teaching, and the integration of Intelligent Tutoring Systems technology into hypermedia environments. He is also interested in instructional methodologies and enhancing the educational environment through project based learning focusing on games development. 